\title{
CORROSION DETERMINATION OF REINFORCEMENT USING THE ELECTRICAL RESISTANCE METHOD
}

\author{
DOLOČANJE KOROZIJE PALICE V ARMIRANEM BETONU S \\ POMOČJO METODE ELEKTRIČNE UPORNOSTI
}

\author{
Miroslav Brodňan ${ }^{1}$, Peter Koteš ${ }^{1}$, Jan Vaněrek ${ }^{2}$, Rostislav Drochytka ${ }^{2}$ \\ 1University of Žilina, Faculty of Civil Engineering, Univerzitná 1, 01026 Žilina, Slovakia \\ ${ }^{2}$ Brno University of Technology, Faculty of Civil Engineering, Veveří 95, 60200 Brno, Czech Republic \\ brodnan@fstav.uniza.sk \\ Prejem rokopisa - received: 2015-07-12; sprejem za objavo - accepted for publication: 2016-01-19
}

doi:10.17222/mit.2015.217

\begin{abstract}
The determination of reinforcement corrosion using the electrical resistance method of embedded bars in the concrete beams in laboratory conditions is described in this paper. For comparison, the achieved data from non-destructive measurements were compared to data from subsequent destructive tests when weight losses were recorded for each of the steel bars after their exposure time. Laboratory measurements of the reinforcements were realized particularly for verification of whether the electrical resistance method could be suitable for an in-situ corrosion-evaluation process. The next part of the research was focused on the corrosion simulation of the steel reinforcement in reinforced concrete. The effect of corrosion was simulated by a nonlinear numerical analysis with the program ATENA 3D using corrosion-rate data from a laboratory test.

Keywords: corrosion, steel, reinforcement, analysis, numerical modeling

$\mathrm{V}$ članku je opisano določanje korozije palic, vgrajenih v betonske stebre, v laboratorijskih pogojih z uporabo metode električne upornosti. Izvedena je bila primerjava podatkov iz neporušnih meritev s podatki iz porušitvenih testov, ko je bilo izmerjeno zmanjšanje teže vsake palice po določenem času. Laboratorijske meritve palic so bile izvedene predvsem za poskus, če je metoda električne upornosti primerna za oceno korozije in situ. Drugi del raziskave je bil usmerjen v simulacijo korozije jeklenih palic v armiranem betonu. Vpliv korozije je bil simuliran z nelinearno numerično analizo, s programom ATENA 3D, z uporabo korozijskih podatkov iz laboratorijskega preizkusa.
\end{abstract}

Ključne besede: korozija, jeklo, armature, analiza, numerično modeliranje

\section{INTRODUCTION}

Nowadays, the tendency in the branch of non-destructive or semi-destructive evaluation methods for the determination of a reinforcement's corrosion leads us to find such a suitable method that can precisely determine the actual state of reinforcement. In economic terms, as well as in terms of implementation, these methods are the most preferred. ${ }^{1,2}$ According to O. Klinghoffer et al., T. Jaśniok and M. Jaśniok et al., J. P. Broomfield and others, it is possible to prevent the further expansion of corrosion by an early localization of the endangered places and thus extend the lifetime of a construction. ${ }^{3-7}$ The corrosion of the reinforcement ordinarily causes a decrease in the adhesion between the reinforcement and concrete, volume changes (shrinkage, concrete creeping) unfavorably affecting the concrete. Finally, the reduction of the reinforcement cross-section impacts on the load-bearing capacity of the structure. For such a precise determination of the corrosion activity process of steel reinforcement, the methods such as the polarization methods, method of electrical resistance, method of half-cell potential, acoustic-emission method and others are applied. ${ }^{8-16}$ The development of non-destructive methods towards not only the methods of measurement by the method of half-cell potential, but also to other methods (polarization method, method of electrical resistance etc.).

For the experimental work, the electrical measurement method (MER) was chosen due to good agreement of the achieved data with the real corrosion state of steel bars. Such a good correlation of the corrosion quantification was proved by the gravimetric method. ${ }^{17,18}$ For these methods, knowledge of the beginning electrical resistance of reinforcement or the continuing measurement of reinforcement are the critical aspects for further corrosion analysis. Because of the semi-destructive nature of the MER method, the access to uncovered reinforcement is an important restriction for its usage.

\section{EXPERIMENTAL PART}

\subsection{Materials}

\subsubsection{Reinforced concrete test beams}

The steel bars with $6 \mathrm{~mm}$ of its nominal size were chosen as the reinforcing bars (steel 10216 grade according to ČSN 41 0216; ČSN 42 5512). Each reinforcement bar prior their usage was weighed, moreover the dimensional properties of the steel bar were recorded. Steel bars were then concreted into beams with dimensions of $50 \mathrm{~mm} \times 50 \mathrm{~mm} \times 340 \mathrm{~mm}$ with a uniform covering of $22 \mathrm{~mm}$. In total, 41 of testing rein- 
M. BRODŇAN et al.: CORROSION DETERMINATION OF REINFORCEMENT USING THE ELECTRICAL ...

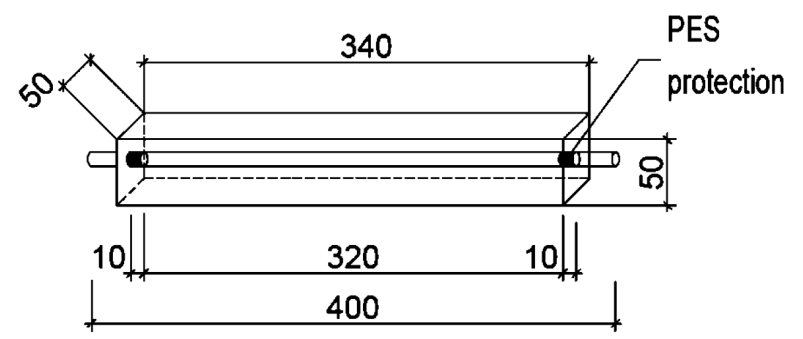

Figure 1: Dimensions of the test concrete sample with embedded steel bar

Slika 1: Dimenzije preizkusnega vzorca betona z vgrajeno jekleno palico

forced concrete beams were prepared using components of $400 \mathrm{~kg}$ of cement (CEM II/B - S 32,5); $1400 \mathrm{~kg}$ of aggregates $(2-4 \mathrm{~mm})$ and $225 \mathrm{~L}$ of water. To accelerate the migration of aggressive media to the steel reinforcement, the fine fraction of aggregates 0-2 $\mathrm{mm}$ was excluded. Another 14 reinforced concrete beams with reinforcement 10216 were made to verify the changes of the electrical conductivity of reinforcement by the different moisture contents of the concrete. During the time of exposure to an aggressive environment, the overhang ends of the reinforcement bars were protected by the plug-polyethylene roller with Vaseline. The steel bars in the length of $10 \mathrm{~mm}$ in the concrete were coated with polyester paint for the elimination of possible resistances losses in this transition region. The scheme of the reinforced concrete beam is shown in Figure 1.

\subsubsection{Short-term exposure of reinforced concrete beams}

The prepared reinforced beams were exposed to cyclic effects of a chloride environment as recommended by RILEM AAC 7.2. It was an intermittent exposure of the beams to a $5 \%$ water solution of $\mathrm{NaCl}$, which were inserted up to $2 / 3$ of its height for $16 \mathrm{~h}$ with a drying process for $8 \mathrm{~h}$ at $40{ }^{\circ} \mathrm{C}$.

\subsubsection{Steel samples}

Measurement of individual samples (not embedded into concrete) of steel reinforcement by MER method. These samples of steel 10505 grade (B 500 according to EN 10080; ČSN 42 0139) with diameters of $(6,8,10$, $12,14,16,18,20,22,25,28,32) \mathrm{mm}$ with a uniform length of $2.0 \mathrm{~m}$. The reason for using the MER method on the steel bars was to find out the meaningful ability of this method or to estimate the limitation of its usage.

\subsection{Methods}

\subsubsection{Electrical resistance measuring method (MER)}

Measuring the changes of electrical resistance of a metal sample is a method that can be applied for the non-destructive monitoring of the corrosion of steel reinforcement in concrete. ${ }^{19-24}$ The principle of this method is based on the fundamental theory regarding the relation of electrical resistance change onto the crosssection size of each conductor, in following Equation (1):

$$
R=\rho \cdot \frac{L}{A}(\Omega)
$$

where $R$ is electrical resistance $(\Omega), \rho$ resistivity of electric conductor $\left(\Omega \mathrm{mm}^{2} \mathrm{~m}^{-1}\right)$, (for steel $\rho=0.098-$ $0.15 \Omega \mathrm{mm}^{2} \mathrm{~m}^{-1}$ at temperature of $\left.20{ }^{\circ} \mathrm{C}\right), L$ length of electric conductor $(\mathrm{m}), A$ cross-sectional area of conductor $\left(\mathrm{m}^{2}\right)$.

Each measuring of the electrical resistance of the steel sample was performed in both polarity of current flow, three measurements for each polarity were performed to minimize the effect of thermoelectric voltage. During the measurement, the temperature of the reinforcement was measured with a contact thermometer in order to eliminate the influence of different temperatures of the reinforcement on the electrical resistance value. The measured resistance was determined at a certain temperature and subsequently recalculated using Equation (2) for the resistance at $20{ }^{\circ} \mathrm{C}$ using a thermal resistance coefficient $\alpha$ for iron $6.2\left(10^{-3} \mathrm{~K}^{-1}\right)$ :

$$
R_{20}=\frac{R}{1+\left[0.0062 \cdot\left(t_{x}-20\right)\right]}(\Omega)
$$

where $t_{\mathrm{x}}$ is temperature of reinforcement $\left({ }^{\circ} \mathrm{C}\right), R_{\mathrm{x}}$ measured resistance of reinforcement $(\Omega)$.

Measurements were undertaken in two different ways: 1) by measuring the electrical resistance using the digital ohmmeter (Figure 2) and 2) by measuring the electric current and voltage to calculate the resulting electrical resistance from these parallel measurements (Figure 3). In the case of using the ohmmeter equipment, the four-connections wiring was used in the range up to $2.00 \mathrm{~m} \Omega$ at current of $3 \mathrm{~A}$ with a measurement sensitivity of $100 \mathrm{n} \Omega$. For measurements using a set of

\section{Digital Ohmmeter}

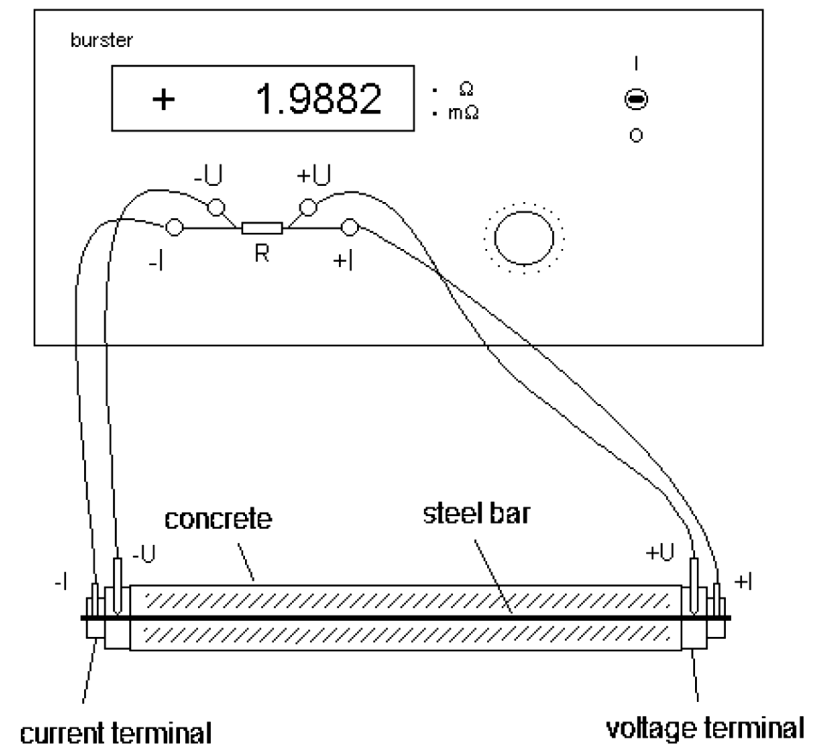

Figure 2: MER of embedded steel bars using digital ohmmeter Slika 2: MER-vgrajene jeklene palice, izmerjen s pomočjo ohmmetra 


\section{MATERIALI IN TEHNOLOGIJE/MATERIALS AND TECHNOLOGY (1967-2017) - 50 LET/50 YEARS}

\section{BRODŇAN et al.: CORROSION DETERMINATION OF REINFORCEMENT USING THE ELECTRICAL ...}

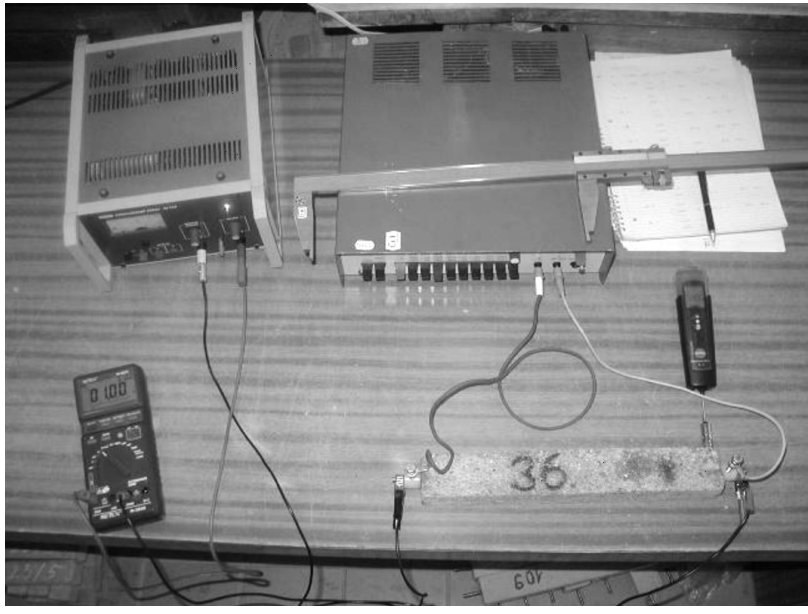

Figure 3: MER of embedded steel bars using a set of apparatus Slika 3: MER-vgrajene jeklene palice, $\mathrm{z}$ uporabo sklopa naprav

apparatus, the millivoltmeter (range of $1 \mathrm{mV} / 10 \mathrm{mV}$ ), ampermeter (range of $2 \mathrm{~A}$ ) and stabilized D.C. power supply were used.

From both MER methods the change of the electrical resistance value can represent the following data of corroded steel elements, in particular Equation (3):

a) effective value of the cross-section reduction RCS, where

$$
R C S=C S_{0} \cdot \frac{\Delta R}{R_{0}}\left(\mathrm{~mm}^{2}\right)
$$

where $C S_{0}$ is initial cross section $\left(\mathrm{mm}^{2}\right), R_{0}$ initial electrical resistance $(\Omega), \Delta R$ difference between the electrical resistance measured at the beginning of measurement $R_{0}$ and $R_{\mathrm{t}}$ measured at the time and

b) value of mass loss $W L_{\mathrm{c}}$

$$
W L_{\mathrm{c}}=R C S \cdot L_{\mathrm{A}} \cdot S_{\mathrm{IR}}(\mathrm{g})
$$

where $L_{\mathrm{A}}$ is length of the active part of the sensor, $S_{\mathrm{IR}}$ specific weight of used iron bar.

\subsubsection{Elemental analysis of steel and corrosive materials}

Elemental analysis was carried out on selected steel bars (as a matrix) and on the corrosion products formed on their surfaces. Analysis was performed on the SEM microscope using $20 \mathrm{kV}$ voltage and an EDX probe for elemental analysis.

\section{RESULTS}

\subsection{Influence of concrete moisture on the electrical resistance of steel bars}

To prove whether the higher amount of concrete moisture content could partially influence its conductivity regarding the change of electrical current, the MER method of tested reinforcements in tested beams with different moisture content was performed. Measurements of electrical resistance were carried out on 14 pieces of reinforcement embedded in concrete beams, which have been continuously exposed to a humid environment, increasing its moisture content. Results of the electrical resistance deviation values are shown in Table 1. The values of moisture content of the concrete cover layer ranged from $3.4 \%$ to $8.9 \%$.

\subsection{Electrical resistance of steel bars with different diameter}

The achieved values of electrical resistance measurements of steel samples with different diameters were compared to nominal values of the cross-sections of the steel bars (Figure 4). The measurement was realized on each reinforcement several times at different distances. Laboratory measurements of different diameters of

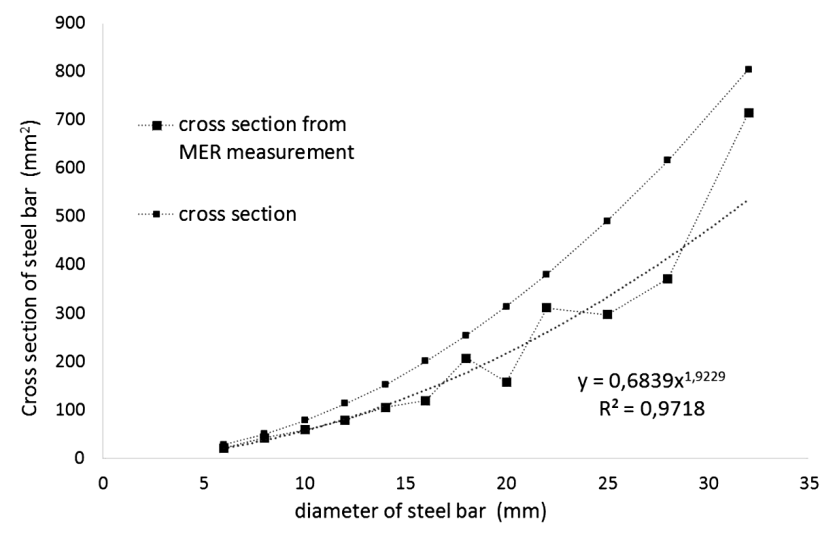

Figure 4: Changes of the cross-sections of steel bars

Slika 4: Spreminjanje preseka jeklenih palic

Table 1: Differences between values of electrical resistance with different moisture content of concrete

\begin{tabular}{|c|c|c|c|c|c|c|c|c|}
\hline \multirow[b]{2}{*}{ No. } & \multicolumn{2}{|c|}{ Electrical resistance } & \multirow[b]{2}{*}{ No. } & \multicolumn{2}{|c|}{ Electrical resistance } & \multirow[b]{2}{*}{ No. } & \multicolumn{2}{|c|}{ Electrical resistance } \\
\hline & $\begin{array}{c}\text { Absolute } \\
\text { difference } \\
(\mathrm{m} \Omega)\end{array}$ & $\begin{array}{c}\text { Relative } \\
\text { difference } \\
(\%)\end{array}$ & & $\begin{array}{c}\text { Absolute } \\
\text { difference } \\
(\mathrm{m} \Omega)\end{array}$ & $\begin{array}{c}\text { Relative } \\
\text { difference } \\
(\%)\end{array}$ & & $\begin{array}{c}\text { Absolute } \\
\text { difference } \\
(\mathrm{m} \Omega)\end{array}$ & $\begin{array}{c}\text { Relative } \\
\text { difference } \\
(\%)\end{array}$ \\
\hline 1 & 0.13 & 2.4 & 6 & 0.13 & 2.5 & 11 & 0.11 & 2.2 \\
\hline 2 & 0.07 & 1.4 & 7 & 0.11 & 2.0 & 12 & 0.10 & 2.0 \\
\hline 3 & 0.08 & 1.6 & 8 & 0.09 & 1.7 & 13 & 0.11 & 2.0 \\
\hline 4 & 0.13 & 2.5 & 9 & 0.16 & 3.1 & 14 & 0.09 & 1.7 \\
\hline 5 & 0.13 & 2.4 & 10 & 0.09 & 1.7 & & & \\
\hline
\end{tabular}

Tabela 1: Razlike med vrednostmi električne upornosti pri različni vsebnosti vlage v betonu 


\section{MATERIALI IN TEHNOLOGIJE/MATERIALS AND TECHNOLOGY (1967-2017) - 50 LET/50 YEARS}

\section{BRODŇAN et al.: CORROSION DETERMINATION OF REINFORCEMENT USING THE ELECTRICAL ...}

reinforcements were realized particularly for verification, whether there is the possibility and good correlation of its usage. Regarding the positive results, the method could be used for in-situ corrosion monitoring process.

\subsection{Electrical resistance of reinforced steel bars}

Figure 5a shows the changes in electrical resistance of the reinforcements in concrete, which were calculated from electrical data of the electrical voltmeter and the current. Figure 5b shows the changes in electrical resistance of the reinforcements, in which a digital ohmmeter was used for the measurement.

For some bars, evaluations of their weight losses were realized to verify the achieved values of weight losses $W L_{\mathrm{c}}$ calculated according to Equation (4), to those detected from built-in steel bars after exposure time. A comparison of both weights losses is listed in Table 2.

Moreover, elemental analyses of the steel and corrosive products were performed for the detailed specification of the used steel material (matrix). Further, the images specify the morphological manifestations of the created corrosive processes on the reinforcement surfaces (Figure 6) regarding the influence of the $\mathrm{Cl}^{-}$ions in the exposure environment.

Table 3: Determined values of elemental analysis of the matrix of monitored steel reinforcements

Tabela 3: Elementna analiza preiskovanega jekla za ojačanje

\begin{tabular}{|c|c|c|c|}
\hline \multirow{2}{*}{$\begin{array}{c}\text { Specimen } \\
\text { number }\end{array}$} & \multicolumn{3}{|c|}{ Component contents $(w / \%)$} \\
\cline { 2 - 4 } & $\mathrm{Fe}$ & $\mathrm{Si}$ & $\mathrm{Mn}$ \\
\hline 10 & 99.06 & $\left.0.24^{*}\right)$ & 0.69 \\
\hline 33 & 98.88 & - & 1.12 \\
\hline
\end{tabular}

*inclusions
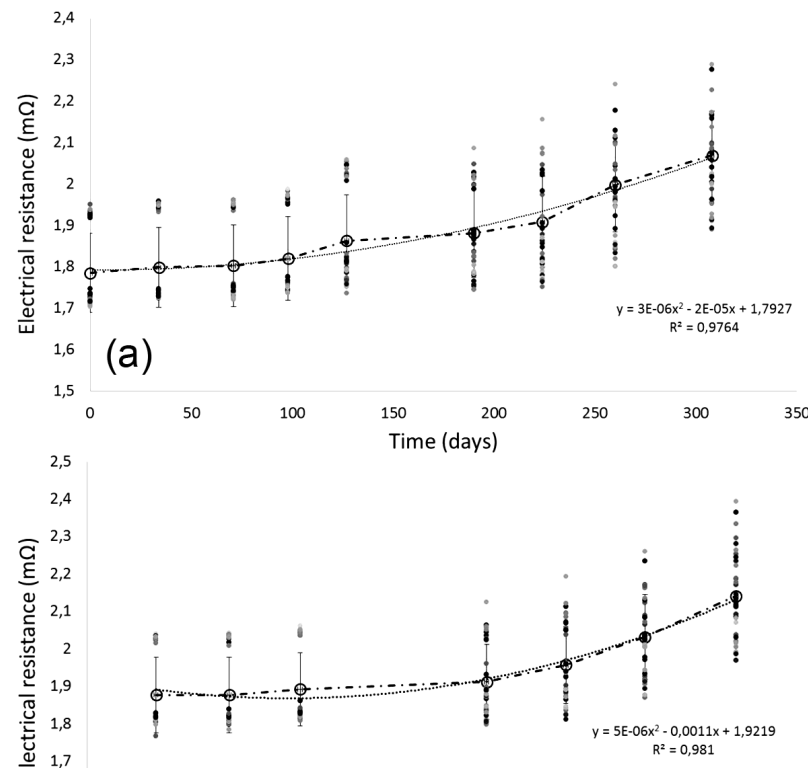

(b)

1,5

$\begin{array}{ccccccc}50 & 100 & 150 & 200 & 250 & 300 & 350 \\ & & \text { Time (days) } & & & \end{array}$

Figure 5: a) Scheme of changes of electrical resistance of steel bars embedded in concrete measured by the indirect method (current and voltage measurements), b) scheme of changes of electrical resistance of steel bars embedded in concrete measured by the direct method with ohmmeter

Slika 5: a) Prikaz spremembe električne upornosti jeklenih palic, vgrajenih $\mathrm{v}$ beton, izmerjene s posredno metodo (meritve tokov in napetosti), b) spreminjanje električne upornosti jeklenih palic, vgrajenih $\mathrm{v}$ beton, izmerjene $\mathrm{z}$ neposredno metodo $\mathrm{z}$ ohmmetrom

Table 2: Detected values of weight losses in selected testing specimens and calculated weight losses $W L_{c}$ determined by the MER method Tabela 2: Izmerjene vrednosti zmanjšanja teže pri izbranih preizkusih vzorcev in izračunano zmanjšanje teže $W L_{c}$, določeno $\mathrm{z}$ MER-metodo

\begin{tabular}{|c|c|c|c|c|c|c|c|c|c|c|c|}
\hline \multirow{2}{*}{ No. } & $\begin{array}{c}\text { Weight } \\
\text { loss } \\
(\Delta \mathrm{m})\end{array}$ & $\begin{array}{c}\text { Bar } \\
\text { diameter } \\
(\mathrm{d})\end{array}$ & $\begin{array}{c}\text { Bar } \\
\text { length }\end{array}$ & $S_{\mathrm{IR}}$ & $\begin{array}{c}\text { Corroded } \\
\text { length }\end{array}$ & $C S_{0}$ & $R_{\mathrm{t}}$ & $R_{0}$ & $\Delta R$ & $R C S$ & $W L_{\mathrm{c}}$ \\
\hline & $\mathrm{g}$ & $\mathrm{mm}$ & $\mathrm{mm}$ & $\mathrm{g} . \mathrm{mm}^{-3}$ & $\mathrm{~mm}$ & $\mathrm{~mm}^{2}$ & $\mathrm{~m} \Omega$ & $\mathrm{m} \Omega$ & $\mathrm{m} \Omega$ & $\mathrm{mm}^{2}$ & $\mathrm{~g}$ \\
\hline 6 & 8.13 & 5.96 & 380 & 0.00739 & 320 & 27.90 & 1.95491 & 1.71854 & 0.23637 & 3.84 & 9.07 \\
\hline 8 & 10.94 & 6.05 & & 0.00741 & 319 & 28.75 & 2.16592 & 1.93429 & 0.23163 & 3.44 & 8.14 \\
\hline 9 & 11.61 & 5.99 & & 0.00728 & 321 & 28.18 & 2.07425 & 1.71940 & 0.35484 & 5.82 & 13.58 \\
\hline 12 & 12.32 & 5.93 & & 0.00742 & 320 & 27.62 & 2.03967 & 1.73674 & 0.30292 & 4.82 & 11.44 \\
\hline 13 & 13.49 & 5.96 & & 0.00733 & 321 & 27.90 & 2.09727 & 1.73019 & 0.36708 & 5.92 & 13.92 \\
\hline 14 & 12.31 & 6.05 & & 0.00743 & 322 & 28.75 & 2.22707 & 1.91870 & 0.30837 & 4.62 & 11.05 \\
\hline 17 & 13.96 & 6.09 & & 0.00704 & 319 & 29.13 & 2.09929 & 1.71212 & 0.38717 & 6.59 & 14.80 \\
\hline 18 & 8.74 & 5.86 & & 0.00763 & 321 & 26.97 & 1.95222 & 1.71118 & 0.24103 & 3.80 & 9.30 \\
\hline 22 & 6.80 & 6.24 & & 0.00696 & 321 & 30.58 & 2.09572 & 1.92223 & 0.17349 & 2.76 & 6.17 \\
\hline 23 & 7.63 & 6.02 & & 0.00714 & 318 & 28.46 & 1.96267 & 1.71653 & 0.24614 & 4.08 & 9.27 \\
\hline 29 & 11.91 & 5.98 & & 0.00731 & 323 & 28.09 & 2.08694 & 1.72167 & 0.36527 & 5.96 & 14.07 \\
\hline 32 & 12.83 & 5.91 & & 0.00777 & 321 & 27.43 & 2.27632 & 1.91798 & 0.35834 & 5.13 & 12.78 \\
\hline 36 & 9.22 & 6.02 & & 0.00718 & 319 & 28.46 & 2.01649 & 1.73438 & 0.28211 & 4.63 & 10.61 \\
\hline 37 & 9.35 & 6.00 & & 0.00728 & 321 & 28.27 & 2.03956 & 1.92749 & 0.11207 & 1.64 & 3.84 \\
\hline 38 & 8.59 & 6.17 & & 0.00708 & 317 & 29.90 & 2.13750 & 1.93679 & 0.20072 & 3.10 & 6.96 \\
\hline 39 & 8.74 & 6.18 & & 0.00707 & 321 & 30.00 & 2.17311 & 1.93828 & 0.23483 & 3.63 & 8.25 \\
\hline
\end{tabular}




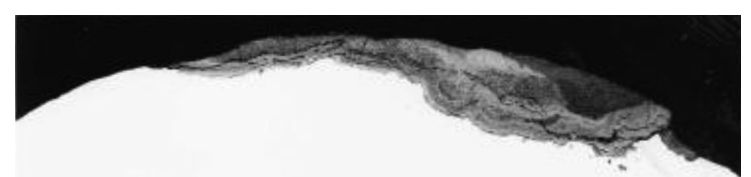

(a)

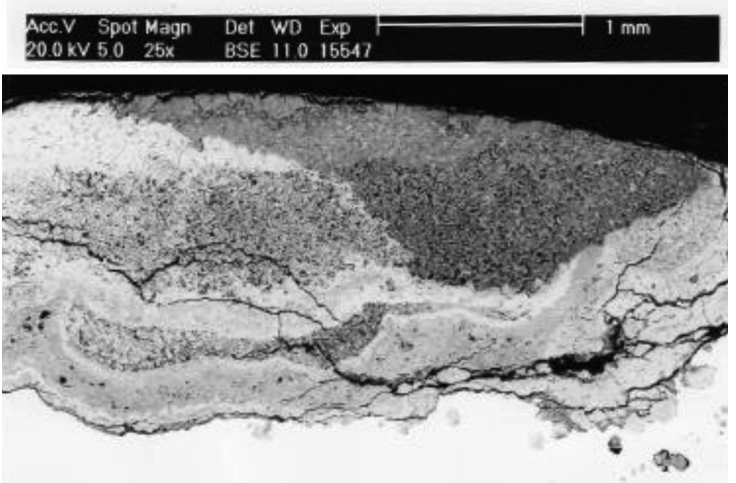

(b)

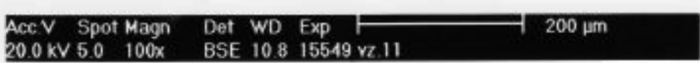

Figure: 6: Detail of morphology of the corrosive processes on the surface of reinforcement: a) max. $25 \times$, b) $\max$. $100 \times$

Slika 6: Detajl morfologije korozijskega procesa na površini palice za ojačanje, povečava: a) max. $25 \times$, b) max. $100 \times$

\section{DISCUSSION}

\subsection{Influence of concrete moisture on the electrical resistance of steel bars}

According to the achieved results, it can be concluded that the increased electrical conductivity of fully soaked concrete cover layer did not affect measured values of electrical resistance. For the in-situ application of the MER method, the moisture content of concrete has negligible influence on the performed measurements.

\subsection{Measured electrical resistance of steel bars}

The difference between values of the cutting crosssections calculated from achieved electrical resistances measured on the uncovered steel bars reinforcement and designed cross-sections values of each bars was found, as shown in Figure 4. Due to these findings, the evaluation of the embedded steel reinforcement cannot be undertaken after a single measurement. Despite this fact, very significant correlations were found in the experimental after long-term exposure of reinforced concrete samples bars. The two methods of electrical resistance measurements were used for quantitative measurements of the steel corrosions, where a slight constant difference between achieved values between these two methods were found. In terms of long-term monitoring of corrosion process, the electrical resistance changes of the average value of $15.9 \%$ using the indirect method (resistance was calculated from voltage and current) and $14.0 \%$ using measurements using ohmmeter equipment were found. In both cases, this change was obtained during the cyclic exposure to a corrosive environment for $308 \mathrm{~d}$ and $320 \mathrm{~d}$, respectively.

\section{INFLUENCE OF REINFORCEMENTS CORROSION ON THE CRACK WIDTH}

The results from the experimental measurements were used for a numerical simulation of corrosion influence on cracking in concrete. The numerical modeling (with the program ATENA 3D) of the reinforcement corrosion confirms that already the small corrosion causes the formation of cracks within the cross-section near the reinforcement. With increasing corrosion, the cracks are going through the concrete cover to the surface of the member. So, it has a strong effect on reducing the remaining lifetime of structures not only due to Ultimate Limit States (ULS) of structure, but also due to Serviceability Limit States (SLS). The significance of the influence depends on the aggressiveness of environment. From this view, the most influenced elements are the members of bridges.

\subsection{Experimental measurements}

Corrosion has a great effect on the structure in terms of the ultimate limit state and serviceability limit state. Thus, the corrosion not only decreases the reinforcement cross-section area, thus decreasing the resistance, but it also increases the volume of the corrosive products (rust), giving rise to tensile and compressive stresses and then cracks, which are undesirable in terms of serviceability. ${ }^{25-27}$

Due to corrosion, cracks occurred in the bulk and on the surface of the specimens. The maximum measured

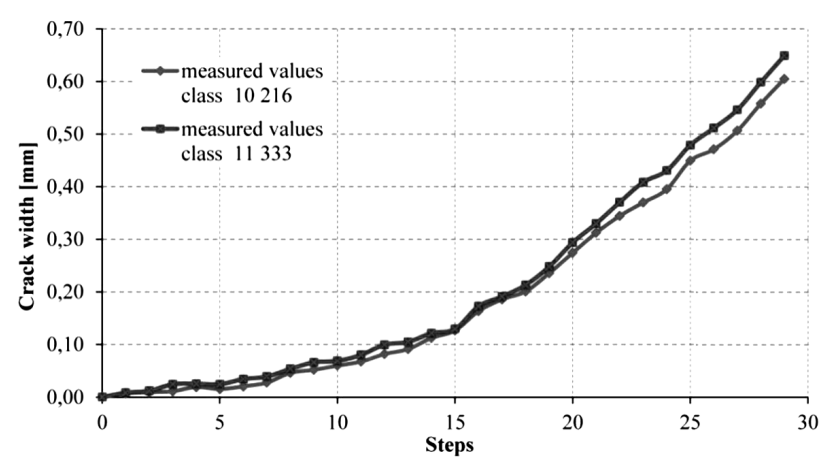

Figure 7: Average values of maximum crack width - measurements on surface

Slika 7: Povprečne vrednosti maksimalne širine razpoke - meritve na površini 


\section{BRODŇAN et al.: CORROSION DETERMINATION OF REINFORCEMENT USING THE ELECTRICAL ...}
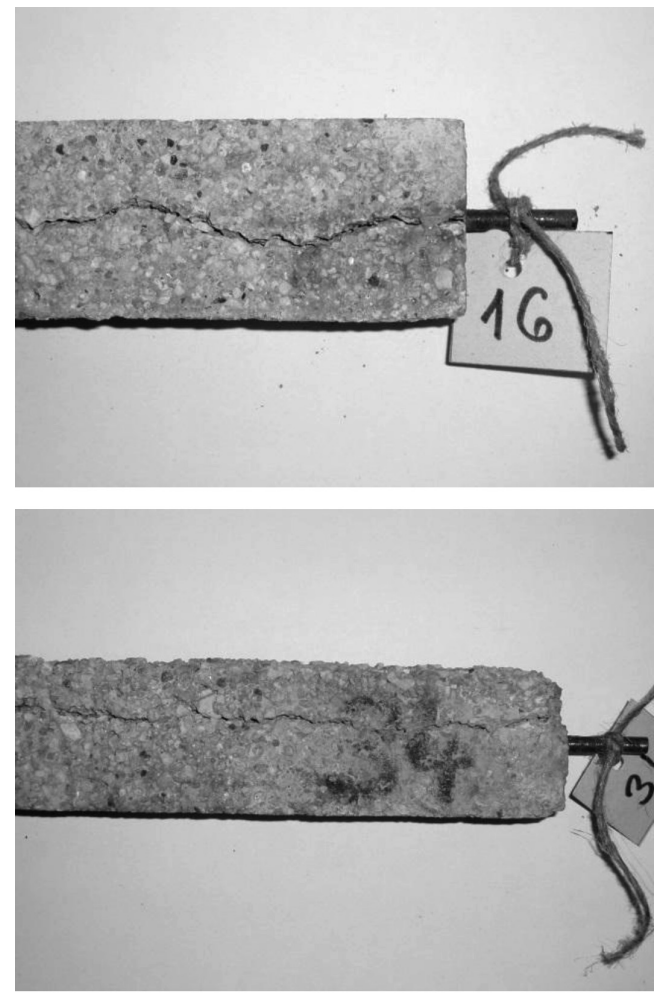

Figure 8: Photographs - crack on surface

Slika 8: Posnetka - razpoka na površini

crack width was $0.60 \mathrm{~mm}$ in the case of beams with steel class 10216 and $0.65 \mathrm{~mm}$ in the case of tube class 11333 . The values from the experiment shown in Figure 7 are the average values of the measurements. The marginal cracks on surface of some specimens are shown in Figure 8 .

\subsection{Numerical modeling of reinforcement corrosion}

The influence of reinforcement corrosion was numerically modeled with the 3D software ATENA. Only the specimens (small beams) with smooth-faced reinforcement class 10216 were modeled.

The reinforcement volume is decreasing with time, but the total volume, including the rust ring, is increasing (Figure 7). The software ATENA does not have the function "corrosion", it is necessary to use another way to model it. So, the total volume increasing due to corrosion was entered into the model as load using a shrink- age function, but with the opposite value so as to cause an increase of the reinforcement volume. This load was evenly distributed within the cross-section and incrementally increases with load steps.

The reinforcement cross-section area is decreasing due to corrosion, while the volume of the corrosive products (rust) increases with percentage p. ${ }^{28,29}$ Due to this phenomenon, it was necessary to recalculate the reinforcement diameter $\phi(\mathrm{t})$ at time $t$ and also the percentage loss of the cross-section area of the embedded reinforcement (Figure 9).

The total area of reinforcement at time $t$ is calculated as:

$$
\begin{aligned}
A_{\mathrm{s} 1, \mathrm{total}}(t) & =A_{\mathrm{s} 1} \cdot\left(1+p^{*}\right)\left(\mathrm{mm}^{2}\right) \\
A_{\mathrm{s} 1} & =\frac{\pi \cdot \phi^{2}}{4}\left(\mathrm{~mm}^{2}\right)
\end{aligned}
$$

where $A_{\mathrm{s} 1}$ is the reinforcement cross-section without corrosion, $p^{*}$ is the percentage loss of reinforcement cross-section, whereas the experiment confirmed a $6 \%$ increase of corrosion during the testing period, hence follows $p=0.06$. The diameter $\phi(t)$ depending on time $t$ was calculated from the Equation (7):

$$
f(t)=\sqrt{\frac{\left(-A_{\mathrm{s} 1, \text { total }}(t)+\frac{\pi}{4} \phi^{2}(1+p)\right) \cdot 4}{\pi \cdot p}}\left(\mathrm{~mm}^{2}\right)
$$

Subsequently, the percentage loss of reinforcement cross-section area was calculated in Equation (8):

$$
p^{*}=\frac{A_{\mathrm{s} 1, \text { total }}(t)}{A_{\mathrm{s} 1}}-1(-)
$$

A material "3D Bilinear Steel Von Mises" was used for reinforcement class 10216 modeling, and a material "3D Nonlinear Cementitious 2" was used for modeling concrete elements with strength $f_{\mathrm{c}}=25 \mathrm{MN} \mathrm{m}^{-2}$. In the $3 \mathrm{D}$ version of ATENA, the crack width is evaluated in volume, not at an accurate point. The crack is propagating from inside out (to surface) and the maximum width is near reinforcement, not on the surface. Thus, to compare the relevant crack width on the surface, the concrete part of the specimen was divided into two parts - core and ring around core with a width of $3 \mathrm{~mm}$ (Figure 10). A contact between those two elements was considered as rigid. The reinforcement cross-section was a)

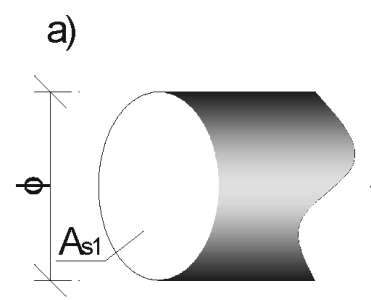

b)

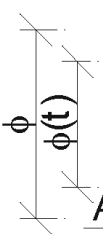

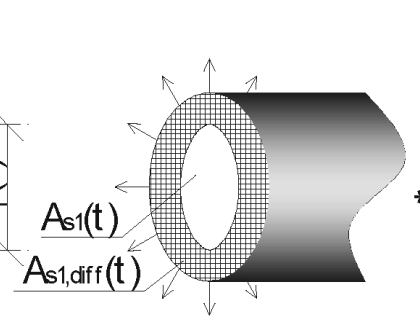
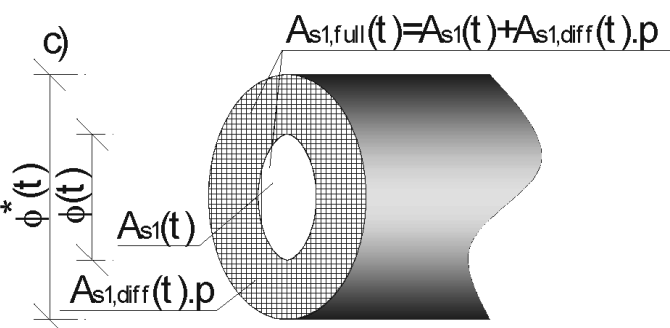

Figure 9: Change of the reinforcement cross-section area due to corrosion - theoretical approach Slika 9: Spreminjanje površine preseka palice za ojačanje, zaradi korozije - teoretični približek 
M. BRODŇAN et al.: CORROSION DETERMINATION OF REINFORCEMENT USING THE ELECTRICAL ...

modeled as a hexagon with the same cross-section area as the original circle, because the 3D version of ATENA does not allow us to model circular cross-sections. The monitors for crack width were given as global for concrete ring macro elements and for all the three axes of the coordinate system $(x, y, z)$.

The next important part of the work was also modeling the contact between concrete and reinforcement. In the case of the 3D version of ATENA, the function "shrinkage" with the opposite value is applied for the whole volume of a given macro element. It means an increase of volume, not only in cross-section, but also in longitudinal direction. The increase of volume in the longitudinal direction also causes tension stresses in the longitudinal direction in concrete and subsequently cracks perpendicular to reinforcement. It is not a real state, so it is needed to model the contact, which transfers just the normal stresses in cross-section, but not the shear stresses between reinforcement and concrete. The material model "3D Interface" was used in ATENA. This model is used for contact modeling between the two different elements.

The interface material model "3D Interface" is based on the Mohr-Coulomb criterion with tension cut off. The constitutive relation for a general three-dimensional case is given in terms of tractions on interface planes and relative sliding and opening displacements, and it is given by Equation (9):

$$
\left\{\begin{array}{l}
\tau_{1} \\
\tau_{2} \\
\sigma
\end{array}\right\}=\left[\begin{array}{ccc}
K_{\mathrm{tt}} & 0 & 0 \\
0 & K_{\mathrm{tt}} & 0 \\
0 & 0 & K_{\mathrm{nn}}
\end{array}\right] \cdot\left\{\begin{array}{l}
\Delta v_{1} \\
\Delta v_{2} \\
\Delta u
\end{array}\right\}(\mathrm{MPa})
$$

where $\tau$ is the shear stress in direction $x$ and $y, \sigma$ is the normal stress, $\Delta v$ is the relatively displacement on surface, $\Delta u$ is the relatively opening of contact, $K_{\mathrm{tt}}$ is the initial elastic shear stiffness, $K_{\mathrm{nn}}$ is the initial elastic normal stiffness.

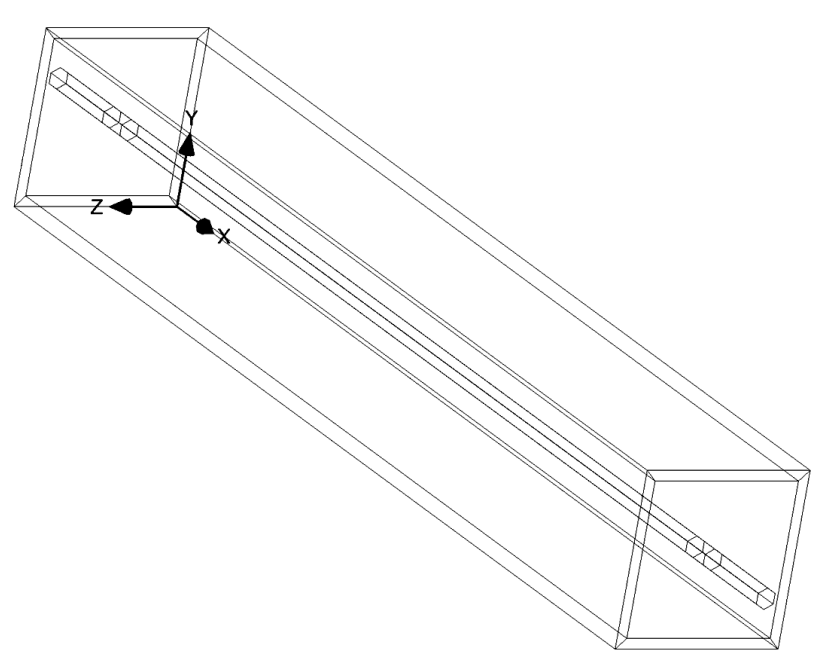

Figure 10: The 3D model in ATENA

Slika 10: 3D model ATENA

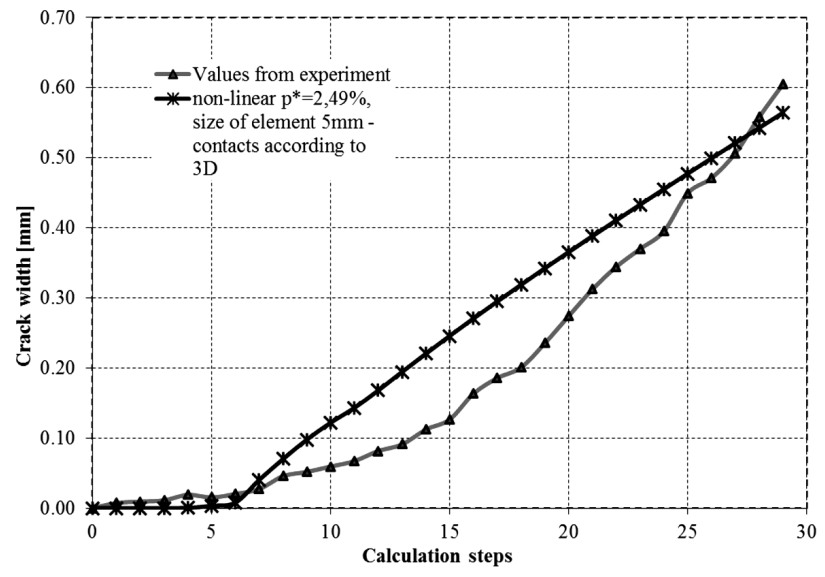

Figure 11: Comparison of crack width from experiment and numerical model

Slika 11: Primerjava širine razpoke iz eksperimenta in numeričnega modela

The initial failure surface corresponds to the MohrCoulomb condition with tension cut off:

$$
\begin{gathered}
|\tau| \leq c+\sigma \phi \text { for } \sigma \leq f_{t}(\mathrm{MPa}) \\
\tau=0 \text { for } \sigma>f_{t}(\mathrm{MPa})
\end{gathered}
$$

where $c$ is the cohesion, $\phi$ is the coefficient of friction, $f_{\mathrm{t}}$ is the tensile strength on surface.

After stresses violate this condition, the surface collapses to a residual surface, which corresponds to dry friction.

The cohesion $c$ is equal to surface stresses $\sigma_{\text {surf }}$ and the value $c=0$ was considered. Also, the coefficient of friction and tensile strength equal to zero were considered $\left(\phi=0, f_{\mathrm{t}}=0\right)$. The values of the initial elastic normal and shear stiffness are estimated from Equation (12):

$$
K_{\mathrm{nn}}=\frac{E}{t_{1}}, \quad K_{\mathrm{tt}}=\frac{G}{t_{1}}\left(\mathrm{MN} / \mathrm{m}^{3}\right)
$$

where $E$ is the minimal elastic modulus, $G$ is the minimal shear modulus, $t_{1}$ is width of the interface zone.

The values $K_{\mathrm{nn}}=3.0 \cdot 10^{6} \mathrm{MN} / \mathrm{m}^{3}$ and $K_{\mathrm{tt}}=1.0 \cdot 10^{-3} \mathrm{MN} / \mathrm{m}^{3}$ were considered to transfer the compressive stresses from reinforcement to concrete in

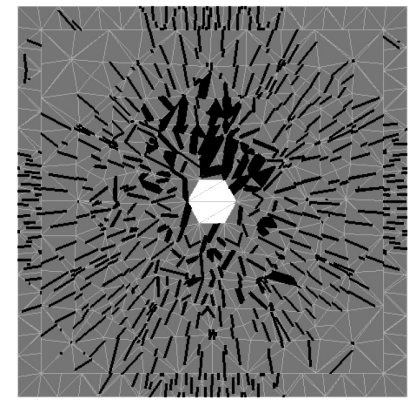

a) Plotting without deformation 3D model

Slika 12: Napredovanje razpok od znotraj navzven pri 3D modelu 
the transverse direction and to ensure the slip between reinforcement and concrete in the longitudinal direction. It eliminates the creation of tensile stresses in the longitudinal direction.

The value $p^{*}=2.488 \%$ was determined from Equation (8). This value best represents the measured values from the experiment (curves in Figure 11). The high consistency of the results can be seen in Figure 11.

The crack propagation and crack pattern in the middle cross-section are shown in Figure 12.

\section{CONCLUSIONS}

A great advantage of these methods is the fact that in the case when the reinforcements with known entrance electrical resistance are inserted into the structural element, we can relatively easily and inexpensively determine the status of other reinforcements, without the destructive interference with the concrete cover layer.

From the obtained results it is possible to conclude that this monitoring method is useful for the quantity corrosion reinforcement evaluation. The determination of the actual state of steel bars is a major criterion in the decision-making process for consequent reinforced-concrete structures redevelopment. The numerical modeling of reinforcement corrosion confirms that already the small corrosion, namely the small percentage of corroded surface causes the formation of cracks within the cross section near the reinforcement. The increase of corrosion products (rust) causes the connection of cracks from within to outside due to an increase of the radial tensile stresses. Those cracks weaken the bond between the concrete and the reinforcement and consecutive concrete cover dropping out.

In practice, it means that it is necessary to place greater emphasis on diagnostics in cases where the corrosion of the reinforcement was identified. Moreover, it means to verify the rate of concrete cover damage and the decrease of the bond. Based on the diagnostics and analysis, it is necessary to consider carefully whether it is possible to retain moderately damaged parts of concrete cover and repair them, or is it necessary to replace one by the new layer.

In conclusion, it is important to emphasize the need for a combination of different methods in monitoring the state of the steel reinforcement in terms of obtaining, if possible, the most comprehensive quantitative and qualitative information. Therefore, increasing knowledge related to the further development of research in this area is justified.

\section{Acknowledgement}

The research is supported by the Slovak Research and Development Agency under contract No. APVV-0106-11 and by Research Project No. 1/0566/15 of Slovak Grant Agency. The authors would like to acknowledge the support of Internal Specific Research project of Brno University of Technology, No. FAST-S-14-2570 and financial support of GACR research project No. 14-25504S "Research of Behavior of Inorganic Matrix Composites Exposed to Extreme Conditions" of Czech Science Foundation.

\section{REFERENCES}

${ }^{1}$ V. M. Malhotra, N. J. Carino, Nondestructive Testing of Concrete, CRC Press LLC, USA 2004

${ }^{2}$ J. Hoła, J. Bień, Ł. Sadowski, K. Schabowicz, Non-destructive and semi-destructive diagnostics of concrete structures in assessment of their durability, Bulletin of the Polish Academy of Sciences Technical Sciences, 63 (2015) 1, 87-96, doi:10.1515/bpasts-2015-0010

${ }^{3}$ FIB Bulletin 34: Model Code for Service Life Design. International Federation for Structural Concrete, Lausanne, 2006, 110

${ }^{4}$ O. Klinghoffer, T. Frolund, E. Poulsen, Rebar corrosion rate measurements for service life estimates, ACI Fall Convention, Toronto, Canada, 2000

${ }^{5}$ T. Jaśniok, M. Jaśniok, A. Zybura Studies on corrosion rate of reinforcement in reinforced concrete water tanks, Ochrona przed korozja, 56 (2013), 227-234

${ }^{6}$ T. Jaśniok, M. Jaśniok, Electrochemical tests on corrosion of the reinforcement in reinforced concrete silos for cement, Ochrona przed korozja, 57 (2014), 225-229

${ }^{7}$ J. P. Broomfield, Corrosion of Steel in Concrete. Understanding, investigation and repair, E\&FN Spon London, 1997, 240

${ }^{8}$ R. Polder, C. Andrade, B. Elsener, O. Vennesland, J. Gulikers, R. Weidert, M. Raupach, Test methods for on site measurement of resistivity of concrete, RILEM, Materials and Structures, 33 (2000), 603-611

${ }^{9}$ V. Živica, Improved method of electrical resistance - a suitable technique for checking the state of concrete reinforcement. Materials and Structures, 26 (1993), 328-332

${ }^{10}$ J. Rodríguez, L. M. Ortega, A. M. Garcia, On-site corrosion measurements in concrete structures. Concrete repair, NovemberDecember 1995, 27-30

${ }^{11}$ C. M. Hansson, Comments on electrochemical measurements of the rate of corrosion of steel in concrete, Cement and concrete research, 4 (1984), 574-584

${ }^{12}$ S. Feliú, C. Andrade, J. A. González, C. Alonso, A new method for in-situ measurement of electrical resistivity of reinforced concrete. RILEM, Materials and Structures, 29 (1996), 362-365

${ }^{13}$ L. Sadowski, Methodology for assessing the probability of corrosion in concrete structures on the basis of half-cell potential and concrete resistivity measurements, The Scientific World Journal, 2013, doi:10.1155/2013/714501

${ }^{14}$ ASTM C 876-91 Standard Test Method for Half-Cell Potentials of Uncoated Reinforcing Steel in Concrete, ASTM International, West Conshohocken, 1999

${ }^{15}$ ASTM G59-97 Standard Test Method for Conducting Potentiodynamic Polarization Resistance Measurements, ASTM International, West Conshohocken, 2003

${ }^{16}$ L. Pazdera, L. Topolar, M. Korenska, T. Vymazal, J. Smutny, V. Bilek, Monitoring early-age concrete with the acoustic-emission method and determining the change in the electrical properties, Mater. Tehnol., 49 (2015) 5, 703-707, doi:10.17222/mit. 2014.112

${ }^{17}$ R. Jambor, V. Živica, Monitoring of steel reinforcement corrosion in concrete by method of electrode potential and electrical resistance. Building Journal, VEDA Bratislava, 30 (1982), 563-586

${ }^{18} \mathrm{~V}$. Živica, Utilisation of electrical resistance method for the evaluation of the state of steel reinforcement in concrete and the rate of its corrosion, Construction and Building Material, 14 (2000), 351-358 


\section{MATERIALI IN TEHNOLOGIJE/MATERIALS AND TECHNOLOGY (1967-2017) - 50 LET/50 YEARS}

\section{BRODŇAN et al.: CORROSION DETERMINATION OF REINFORCEMENT USING THE ELECTRICAL ...}

${ }^{19}$ M. Kouril, T. Prosek, B. Scheffel, Y. Degres, Corrosion monitoring in archives by the electrical resistance technique. Journal of Cultural Heritage 15 (2014), 99-103, doi:10.1016/j.culher.2013.04.002

${ }^{20}$ S. P. Karthick, S. Muralidharan, V. Saraswathy, K. Thangavel, Longterm relative performance of embedded sensor and surface mounted electrode for corrosion monitoring of steel in concrete structures. Sensors and Actuators B: Chemical, 192 (2014), 303-309

${ }^{21}$ I. Martinez, C. Andrade, Examples of reinforcement corrosion monitoring by embedded sensors in concrete structures, Cement \& Concrete Composites, 32 (2009), 545-554

${ }^{22} \mathrm{C}$. Andrade, C. Alonso, Corrosion rate monitoring in the laboratory and on-site, Construction and Building Materials, 10 (1996), 315-328

${ }^{23}$ A. J. Garzon, J. Sanchez, C. Andrade, N. Rebolledo, E. Menéndez, J. Fullea, Modification of four point method to measure the concrete electrical resistivity in presence of reinforcing bars, Cement and Concrete Composites, 53 (2014), 249-257, doi:10.1016/ j.cemconcomp.2014.07.013

${ }^{24} \mathrm{~V}$. Živica, Utilisation of electrical resistance method for the evaluation of the state of steel reinforcement in concrete and the rate of its corrosion, Construction and Building Material, 14 (2000), $351-358$
${ }^{25}$ J. Bilčík, L. Fillo, V. Benko, J. Halvoník, Concrete Structures, Design by STN EN 1992-1-1, STU Bratislava, 2008, 374

${ }^{26}$ V. Borzovič, J. Halvoník, Flat Slab Reinforcement with Regard to the Distribution and Redistribution of Internal Forces, Third international workshop Design of concrete structures using Eurocodes, Vienna, Grafische Zentrum HTU GmbH, 2012, 223-228

${ }^{27}$ K. Gajdošová, Stress and Crack Width Control According to EN 1992, Third international workshop Design of concrete structures using Eurocodes, Vienna, Grafische Zentrum HTU GmbH, 2012, 199-202

${ }^{28}$ P. Koteš, M. Brodňan, K. Šlopková, P. Kotula, Numerical modelling of reinforcement corrosion in reinforced concrete, Journal Ochrona przed korozja, 53 (2010) 6, 307-309

${ }^{29}$ P. Koteš, M. Brodňan, K. Šlopková, Simulation of corrosion of reinforcement in reinforced concrete. International RILEM Symposium on Concrete Modelling - CONMOD 08, CD, Delft - The Netherlands, 2008, [Edited by Erik Schlangen \& Geert De Schutter, 2008], $761-766$ 